\title{
SEEd CotTon AND Lint Moisture AdDition AT A WESTERN COTTON GIN
}

\author{
D. P. Whitelock, C. B. Armijo, C. D. Delhom
}

ABSTRACT. Testing was conducted at a western commercial cotton gin to evaluate the effect of humid air moisture addition on fiber quality, bale value, and operating costs; when applied at the gin stand feeder conditioning hopper and battery condenser lint slide. Two tests each with 19 conventional modules of upland cotton were conducted over two consecutive days. The moisture treatments included feeder hopper moisture on or off and lint slide moisture on or off, resulting in four treatment combinations: 1) no moisture added (No Addition), 2) moisture added at the feeder hopper only (Hopper Only), 3) moisture added at the lint slide only (Slide Only), and 4) moisture added at the both the feeder hopper and lint slide moisture (Hopper+Slide). Results showed that seed cotton moisture content at the gin stand was about 0.1 percentage points higher when moisture was added at the feeder hopper and lint moisture content in the bale was about 0.9 percentage points higher when moisture was added at the lint slide. Adding moisture at the feeder hopper resulted in small, but significant (p-value $\leq 0.05)$, improvements in HVI length [ $+0.21 \mathrm{~mm}(0.008 \mathrm{in})$.$] , uniformity (+0.16$ percentage points), and strength $(+0.25 \mathrm{~g} /$ tex), and AFIS length [+0.4 mm (0.016 in.)] and short fiber content (-0.52 percentage points). However, fiber yellowness also increased $(+0.12+b)$ when moisture was added at the feeder hopper. Adding moisture at the lint slide had very little effect on fiber quality. Moisture addition at either location did not significantly affect spinning performance or yarn quality. Lint produced with moisture added only at the feeder hopper had the highest average value [\$1.254/kg (56.88 $\phi / l b)]$ and lint with moisture added only at the lint slide had the lowest value [\$1.234/kg $(55.98 \mathrm{c} / \mathrm{lb})]$. Bales produced with added moisture were heavier, $9 \mathrm{~kg}(20 \mathrm{lb})$ heavier on average for the Hopper+Slide moisture addition than for No Addition. Bales produced using moisture addition not only contained more moisture, but also more lint. This could be due to easier bale pressing, which was supported by measurements which showed that about $2 \mathrm{~kW}$ less press power was required to press bales with moisture added at the lint slide. Moisture added at the feeder hopper resulted in the greatest overall increase in value over the value of cotton ginned with no moisture addition, more than \$32,000 when extrapolated over 10,000 bales. The moisture addition treatments required more energy to produce bales, mainly due to the additional natural gas required for air humidifying equipment. However, since bales with added moisture contained more dry lint resulting in fewer bales pressed for the same amount of dry lint in bales produced with no moisture addition, savings in bale packaging materials and labor costs made operating the moisture systems slightly less expensive than not, up to about $\$ 1400$ less for 10,000 bales with the Hopper+Slide moisture addition. Although the results showed little impact on cotton quality by adding moisture, the subtle differences and heavier bales containing more lint could have a significant effect on the value to a producer over an entire cotton crop or to a gin over an entire season.

Keywords. Cost benefit analysis, Cotton ginning, Energy, Fiber quality, Humid air, Moisture addition.

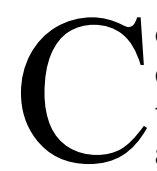

otton moisture content is an important factor in cotton ginning (Hughs et al., 1994). Cotton that is too moist will not open-up into individual locks and thus, will not clean well or gin easily. Cotton

\footnotetext{
(c) (1) $\odot$ The authors have paid for open access for this article. This (c) ${ }_{\text {BY NC ND }}$ work is licensed under a Creative Commons AttributionNonCommercial-NoDerivatives 4.0 International License https:/creative commons.org/licenses/by-nc-nd/4.0/

Submitted for review in September 2017 as manuscript number PRS 12618; approved for publication by the Processing Systems Community of ASABE in April 2018.

Mention of trade names or commercial products in this publication is solely for the purpose of providing specific information and does not imply recommendation or endorsement by the U.S. Department of Agriculture. USDA is an equal opportunity provider and employer.

The authors are Derek P. Whitelock, Agricultural Engineer, and Carlos B. Armijo, Textile Technologist, USDA-ARS Southwestern Cotton Ginning Research Laboratory (SWCGRL), Mesilla Park, New Mexico; and Christopher D. Delhom, Materials Engineer, USDA-ARS Cotton Structure and Quality Research, New Orleans, Louisiana. Corresponding author: Derek P. Whitelock, USDA-ARS Southwestern Cotton Ginning Research Laboratory, PO Box 578, Mesilla Park, NM 88047; phone: 575526-6381; e-mail: derek.whitelock@ars.usda.gov.
}

that is too dry is damaged more easily by mechanical processing in the gin and may cling to itself or to machinery surfaces due to build-up of static charge. The charge inhibits the cotton from opening into individual locks and reduces flow inside machines. Cotton moisture content (MC) of 6 to $7 \%$ wet basis (w.b.) is recommended for effective cleaning, efficient ginning, easier bale packaging, and minimal fiber damage (Valco et al., 2004). Cotton in the bale must be less than $7.5 \% \mathrm{MC}$ w.b. to be eligible for the Commodity Credit Corporation loan program (Cotton - General eligibility requirements, 2015).

Often cotton is over-dried at the gin, so that restoring moisture can improve processing and fiber value (Valco et al., 2004). Generally, there are two types of moisture restoration systems that are used to add moisture to seed cotton before ginning or lint prior to packaging: humidified air and liquid water spray. Humidified air systems utilize heated air with water vapor to impart moisture to the cotton when the 
air and cotton are combined in a conveying duct, in a conditioning hopper before the gin stand feeder, at the battery condenser, or in the lint slide. Spray systems apply liquid water droplets directly, usually at the lint slide. Anthony (2004) surveyed 20 gins in the Midsouth that had lint moisture restoration systems at the battery condenser and/or the lint slide. Most gins over dried their cotton before ginning $(<5 \% \mathrm{MC}$ w.b.). Humid air systems added on average 1.1 to $1.7 \mathrm{~kg}(2.4$ to $3.8 \mathrm{lb})$ of water per bale $(0.5$ to 0.8 percentage points $\mathrm{MC}$ w.b.) with less than $1 \%$ of bales over $7.5 \%$ MC w.b. Spray systems added about $3.2 \mathrm{~kg}$ ( $7 \mathrm{lb})$ of water per bale $(1.5$ percentage points $\mathrm{MC}$ w.b.), but had nearly $23 \%$ of bales had over 7.5\% MC w.b. Since liquid water is more easily overapplied resulting in "wet" bales over 7.5\% MC w.b., few gins currently use spray systems.

\section{Seed Cotton Moisture Addition}

Recent research has shown that there are cotton quality advantages to adding moisture before the gin stand. In 2005, Byler (2005) evaluated the effect of "modest" moisture addition using humid conveying air in the second tower dryer. The moisture addition increased lint moisture by 0.8 percentage points. The cotton with added moisture had better Advanced Fiber Information System (AFIS, Uster Technologies, Knoxville, Tenn.) fiber length properties. AFIS mean length by weight (Lw) was 0.4-mm longer, upper quartile length by weight (UQLw) was $0.3-\mathrm{mm}$ longer, and short fiber content by weight (SFCw) was 0.7 percentage points lower. Also, nep counts were lower (20 neps per $g$ less), but additional moisture was associated with increased foreign matter (total trash count was 60 per $g$ higher and visible foreign matter was 19 percentage points higher).

In another study, Byler (2008) utilized atomizing spray nozzles with unheated water to moisten seed cotton at the conveyor distributor in a commercial gin. Lint moisture between the gin stand and the first lint cleaner was increased on average by 0.7 percentage points w.b. Lw was 23.55 and $23.36 \mathrm{~mm}$, UQLw was 28.14 and $27.98 \mathrm{~mm}$, and SFCw was $8.6 \%$ and $8.9 \%$ for lint with and without moisture addition, respectively. Like the earlier study, foreign matter increased and nep count decreased with moisture addition.

Byler et al. (2008) compared restoring moisture to seed cotton with humid air in a conditioning hopper above the gin stand feeder and with low and high pressure atomizing sprayers at the conveyor distributor. The three methods increased fiber moisture after ginning by $0.28,0.62$, and 1.12 percentage points w.b., respectively. The humid air addition increased UQLw by $0.22 \mathrm{~mm}$ and reduced $\mathrm{SFCw}$ by 0.615 percentage points. The low and high pressure atomizing sprayer applications increased UQLw by 0.20 and $0.37 \mathrm{~mm}$ and reduced SFCw by 0.592 and 0.835 percentage points, respectively. The high pressure atomizing sprayer had higher AFIS trash count (90.5 per g) than no moisture addition (80.7 per g), which resulted in higher mill opening and cleaning waste (1.614\% for spray vs. $1.1410 \%$ for no addition). The high pressure spray addition did, however, result in higher single strand yarn strength $(15.690 \mathrm{~g} / \mathrm{tex})$ and fewer long thin places $(52.7$ per $1000 \mathrm{~m})$ than no moisture addition $(15.288$ $\mathrm{g} /$ tex and 82.5 per $1000 \mathrm{~m})$.
In a study by Boykin (2005) that evaluated moisture addition via humid air in a gin stand feeder conditioning hopper, the fiber quality results were similar to those from Byler (2005) and Byler et al. (2008). Lint moisture content was increased from $4.55 \%$ to $5.08 \%$ w.b., High Volume Instrument (HVI, Uster Technologies, Knoxville, Tenn.) upper half mean length (UMHL) increased from 27.52 to $27.71 \mathrm{~mm}$, and AFIS SFCw decreased from $8.74 \%$ to $7.92 \%$, nep count improved from 247 to 227 per g, and visible foreign matter increased from $1.60 \%$ to $1.75 \%$. Other notable differences between moisture addition and no addition were improvements in immature fiber content $(0.14$ percentage points lower), maturity ratio (0.007 higher), and fineness ( $0.7 \mathrm{mTex}$ higher), but worsening of seed coat neps ( 0.74 neps/g more). Boykin (2005) also measured the gin stand energy consumption and gin turnout, and found that moisture addition reduced gin stand energy per bale by $1.4 \%$ [21.4 down to $21.1 \mathrm{MJ}(5.94$ to $5.86 \mathrm{kWh})$ ] and turnout increase from $35.70 \%$ to $36.08 \%$.

\section{Lint Moisture AdDition}

There have also been several projects since 2000 investigating lint moisture addition at the battery condenser lint slide. Anthony (2002) evaluated the long-term fiber quality impact of adding 0 to $25 \mathrm{~kg}(55 \mathrm{lb})$ of moisture per bale using water spray at the lint slide, after 116 days of storage. Except for color, fiber quality characteristics were similar between moisture treatments. There was prominent color degradation from 31 color grade before storage to 41 for $8.2 \% \mathrm{MC}$ w.b., 42 for $11.6 \% \mathrm{MC}$ w.b., and 43 for $12.9 \% \mathrm{MC}$ w.b. after storage. For those moisture levels, yellowness increased from about $8.5+\mathrm{b}$ before storage to $9.3,10.1$, and $10.6+\mathrm{b}$ after storage, respectively.

Chun et al. (2007) conducted a study to determine acceptable bale moisture levels that avoid fiber quality, yarn quality, and dyed fabric quality degradation after bale storage. The test included water spray application at the lint slide to add $0,4.5,9.1$, and $13.6 \mathrm{~kg}(0,10,20$, and $30 \mathrm{lb})$ of water per bale, resulting in bales with $5.72 \%, 6.68 \%, 8.40 \%$, and $9.50 \%$ MC w.b., respectively, after 6 months storage. HVI micronaire for cotton with the highest moisture content was 5.11 , which is in the "high" range (5.0 and above) that receives a price discount. Color reflectance decreased from 81.6 Rd for no moisture to 77.0 Rd for the highest addition and yellowness increased from 7.7 to $9.3+\mathrm{b}$. Adding $9.1 \mathrm{~kg}$ $(20 \mathrm{lb})$ or more of water to bales of cotton resulted in yarn quality reductions of significantly more yarn neps (10.3 vs. 6.3 per $1000 \mathrm{~m})$, more thick places $(120 \mathrm{vs} .101$ per $1000 \mathrm{~m})$, more thin places (76 vs. 62 per $1000 \mathrm{~m})$, more long thin places (17.3 vs. 8.7 per $1000 \mathrm{~m}$ ), and higher yarn mass variation CV (15.7\% vs. $15.6 \%)$ compared to no moisture addition. Chun et al. (2007) concluded that the point of lint slide moisture addition diminishing returns occurred between the treatments that added 4.5 and $9.1 \mathrm{~kg}$ (10 and $20 \mathrm{lb})$ of water per bale and resulted in $6 \%$ and $8.5 \%$ bale MC w.b.

Baker et al. (2008) used a rotor spray nozzle system to restore lint moisture at the lint slide. They found that bale moisture after adding water should be less than $7.5 \%$ w.b. to avoid color degradation during storage. 
A study conducted by Childers and Baker (1978) to evaluate the effect of moisture restoration at the feeder on bale value found that drying seed cotton without moisture restoration reduced bale value mainly due to moisture weight loss and reduced length. Also, drying at $66^{\circ} \mathrm{C}\left(150^{\circ} \mathrm{F}\right)$ with moisture restoration affected bale value little, while drying at $93^{\circ} \mathrm{C}\left(200^{\circ} \mathrm{F}\right)$ with moisture restoration reduced bale value, but that reduction was less than for drying at either temperature without moisture restoration.

Studies have looked at many aspects of moisture restoration, but have not considered moisture restoration by humid air both at a gin stand feeder conditioning hopper and at the lint slide. Furthermore, there are questions about the cost/benefits of operating these moisture systems. The objective of this study was to evaluate the effect of humid air moisture addition on fiber quality, bale value, and operating costs; when applied at the gin stand feeder conditioning hopper and lint slide battery condenser.

\section{METHODS}

Ginning tests were conducted during the 2015 ginning season at a commercial cotton gin in Arizona. The gin had two moisture addition systems: gin stand feeder conditioning hopper moisture system and battery condenser lint slide moisture system. The feeder hopper moisture addition system was a Samuel Jackson Conditioning Hopper with Humidaire Unit (Samuel Jackson, Inc., Lubbock, Tex.). The lint slide moisture addition system was a Samuel Jackson Super Grid system with King Mesa Humidaire Unit (Samuel Jackson, Inc., Lubbock, Tex.). Target bale moisture for the tests was $7 \%$ w.b. with feedback control provided by a Tex-Max Microwave Bale Moisture Sensor (Samuel Jackson, Inc., Lubbock, Tex.). Target moisture for the gin stand feeder apron was $6.5 \%$ w.b. and was monitored manually throughout the tests with a Delmhorst model C-2000 moisture meter and 52-E/C cup-type electrode (Delmhorst Instrument Co., Towaco, N.J.).

Two tests were conducted over two consecutive days. One test with 19 conventional modules [184,700 kg $(405,000 \mathrm{lb})]$ of one upland cotton cultivar (ST 4946 GLB2) the first day and the second test with 19 conventional modules $[160,800 \mathrm{~kg}(354,500 \mathrm{lb}])$ of a second cultivar (NG 3406 $\mathrm{B} 2 \mathrm{XF}$ ) the second day. The cultivars were selected based on availability of approximately 20 modules of the same cultivar from the same farmer and field for the most uniform material possible.

All combinations of the moisture addition treatments, feeder hopper moisture on or off and lint slide moisture on or off, resulted in four treatment combinations: 1) no moisture added (No Addition), 2) moisture added at the feeder hopper only (Hopper Only), 3) moisture added at the lint slide only (Slide Only), and 4) moisture added at both the feeder hopper and the lint slide (Hopper+Slide). For each cultivar, the four treatment combinations were replicated three times with the run order of the treatments randomized within each replication.

Twenty bales of cotton were ginned for each test run. First, the feeder hopper moisture unit and lint slide moisture unit were set to either off or on as required for the treatment. Then, after five bales were ginned to allow the systems to come to equilibrium, data recording and cotton sample collection occurred over the time that the next 15 bales were ginned. Information recorded included bale numbers for retrieval of cotton classing data, production rate, machinery energy usage, and moisture system data. Cotton samples for moisture analysis were collected three times during each test run at five bale intervals. Seed cotton samples were taken just before the feeder hopper and at the feeder apron to quantify the amount of moisture added by the feeder hopper system. Lint samples were taken from the lint flue before the battery condenser and from the bale before bagging to quantify the amount of moisture added by the lint slide system. Seed cotton and lint moisture analyses were conducted onsite using a modification of the Shepherd (1972) oven-drying method where the samples are weighed outside of the drying oven as per USDA Ginning Laboratory alternative methodology. Official bale lint samples were all classed at the USDA-AMS classing office in Visalia, California.

Machinery motor energy usage was monitored during the tests using split-core current transducers (Hawkeye 921, Veris Industries, Portland, Ore.). The transducers were installed at the motor disconnect on a single leg for motors on the following machinery: press main pump, and No. 1 and No. 2 booster pumps; and fans for the feeder hopper and lint slide moisture systems. More information about the monitoring system hardware and data analysis are available from Funk et al. (2013). Also, the natural gas meter reading was recorded for each test to determine moisture system usage.

Additional lint quality analyses and spinning tests were conducted at the USDA-ARS Southern Regional Research Center in New Orleans, Louisiana. AFIS testing was conducted on the raw fiber samples. Approximately 60 grams of raw cotton from each lint sample collected during ginning was opened using a laboratory scale fiber opener (SpinLab, Knoxville, Tenn.), carded on a modified commercial carding machine, drawn into finisher sliver on a custom drawing frame, and then spun on a miniature ring spinning frame (SDL Atlas, Stockport, UK) into 30/1 yarn with 3.8 twist multiple. Card losses were recorded. Yarn uniformity and single-end strength were measured with Uster Tester 4 and Tensorapid 4 (Uster Technologies, Knoxville, Tenn.), respectively. Skein strength was measured according to ASTM Standard Test Method D1578 (ASTM International, 2016).

Statistical analyses were conducted using JMP (ver. 12.2.0, SAS Institute, Inc., Cary, N.C.). The Fit Model platform with the standard least squares option was used to fit a mixed model with the feeder hopper moisture and lint slide moisture treatments and their interaction (Hopper+Slide) as the main effects, and replication nested within cultivar as a random effect. The recommended restricted maximum likelihood (REML) method option was selected for fitting the mixed models. ANOVA mean differences and p-values were calculated. Also, Cohen's d effect size, defined as the difference between two means divided by the pooled standard deviation, was calculated to aid in interpretation of the significance of the results (Cohen, 1988). Cohen (1988) suggested that magnitudes of $\mathrm{d}=0.2,0.5$, and 0.8 corresponded to small, medium, and large effect sizes. 


\section{RESULTS}

Based on oven-drying method measurements of samples taken before and after the feeder hopper, the seed cotton moisture content increased by about 0.15 percentage points when seed cotton passed through the feeder hopper with moisture addition and decreased by about 0.09 percentage points without moisture addition at the feeder hopper (fig. 1). Based on lint samples taken before and after the lint slide, lint moisture content increased by about 0.47 percentage points when lint passed through the lint slide with moisture addition and decreased by about 0.36 percentage points without moisture addition at the lint slide. When no moisture was added at a location, cotton moisture decreased. For example, with No Addition the cotton moisture content decreased from about $5 \%$ to $4.25 \%$ w.b. from before the feeder to the bale. Thus, the slight gains in moisture content at the feeder hopper did not carry through to the bale.

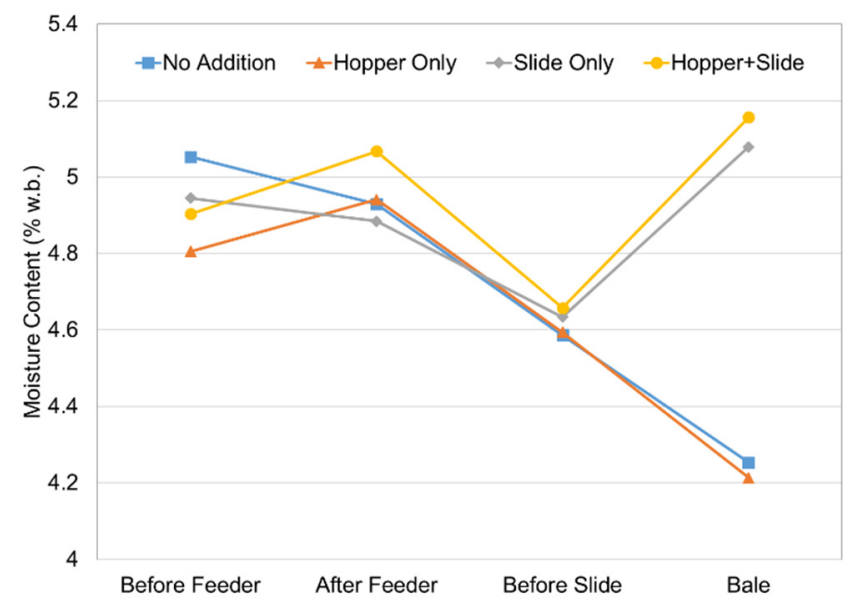

Figure 1. Cotton moisture content before and after the feeder hopper and lint slide moisture additions.

\section{INFERENTIAL STATISTICS}

Feeder hopper moisture addition did not have a significant effect on seed cotton moisture content $(\mathrm{p}$-value $=0.494)$ or bale moisture $(p$-value $=0.889)($ table 1$)$. On the other hand, when lint slide moisture was On, the average bale moisture content was $5.12 \%$ w.b., significantly (p-value $\leq$ 0.05 ) different from $4.23 \%$ when the lint slide moisture was off.

Feeder hopper moisture addition had a significant effect on HVI color, length, and strength properties (table 2); albeit practically the differences were small. Fiber yellowness was significantly different (difference $=0.12+\mathrm{b}$ ) between the feeder hopper moisture Off/On treatments. However, the difference was small and cotton color grades were not different, $\mathrm{Rd}$ and $+\mathrm{b}$ translated to 11 color whether the feeder hopper moisture was Off or On. UHML for feeder hopper moisture On [28.3 mm (1.116 in.)] was significantly different from Off [28.1 mm (1.108 in.)] and d (0.90) indicated a large effect size (Cohen, 1988). But practically, the mean difference of $0.21 \mathrm{~mm}(0.008 \mathrm{in}$.) would only account for about onequarter of a staple length [4/5 mm (1/32 in.)]. Similarly, uniformity index and strength were significantly different $(0.016$ percentage points and $0.25 \mathrm{~g} /$ tex difference, respectively) between feeder hopper moisture Off/On treatments, but the difference in the means did not put them in different loan price schedule premium or discount levels (30-30.9 $\mathrm{g} /$ tex strength $=20$ points premium and $81.0 \%-81.9 \%$ uniformity $=0$ points) (USDA Farm Service Agency, 2015).

Supporting the results for the HVI properties, AFIS length measurements were significantly better when the feeder hopper moisture was On than Off (table 3). Lw and UQLw for feeder hopper moisture On were both about 0.4 $\mathrm{mm}(0.016 \mathrm{in}$.) longer than for Off. Lw CV was lower for feeder hopper moisture On (33.84\%) than for Off (34.42\%) and SFCw was more than 0.5 percentage points lower when the feeder hopper moisture was On. For all the AFIS length measurements in table 3 , the effect size (d) was greater than \pm 0.8 , which indicates a large effect size. Although nep and

Table 1. Mean moisture content (\% w.b.) and statistics due to moisture addition at the feeder hopper and lint slide.

\begin{tabular}{|c|c|c|c|c|c|c|c|c|c|c|c|c|}
\hline \multirow[b]{3}{*}{ Location } & \multicolumn{6}{|c|}{ Feeder Hopper Moisture Addition } & \multicolumn{6}{|c|}{ Slide Moisture Addition } \\
\hline & \multicolumn{2}{|c|}{ Off } & \multicolumn{2}{|c|}{ On } & \multirow[b]{2}{*}{ Difference } & \multirow[b]{2}{*}{ p-value } & \multicolumn{2}{|c|}{ Off } & \multicolumn{2}{|c|}{ On } & \multirow[b]{2}{*}{ Difference } & \multirow[b]{2}{*}{ p-value } \\
\hline & Mean & $\mathrm{SD}$ & Mean & $\mathrm{SD}$ & & & Mean & SD & Mean & $\mathrm{SD}$ & & \\
\hline After Feeder & 4.91 & 0.37 & 5.00 & 0.28 & 0.10 & 0.494 & & & & & & \\
\hline Bale & 4.67 & 0.62 & 4.68 & 0.67 & 0.02 & 0.889 & 4.23 & 0.32 & 5.12 & 0.56 & 0.88 & $<0.001$ \\
\hline
\end{tabular}

Table 2. Means and statistics for HVI fiber properties from feeder hopper moisture addition - Off \& On.

\begin{tabular}{|c|c|c|c|c|c|c|c|}
\hline & \multicolumn{2}{|c|}{ Off } & \multicolumn{2}{|c|}{ On } & \multirow[b]{2}{*}{ Difference } & \multirow[b]{2}{*}{ p-value } & \multirow[b]{2}{*}{$\mathrm{d}^{[\mathrm{b}]}$} \\
\hline & Mean & SD & Mean & SD & & & \\
\hline$\overline{\text { Reflectance (Rd) }}$ & 79.98 & 0.64 & 79.74 & 0.62 & 0.24 & 0.377 & -0.38 \\
\hline Yellowness $(+b)$ & 9.89 & 0.26 & 10.01 & 0.20 & 0.12 & 0.019 & 0.51 \\
\hline Color Grade ${ }^{[a]}$ & 11 & & 11 & & & & \\
\hline Leaf Grade & 2.37 & 0.38 & 2.39 & 0.48 & 0.022 & 0.873 & 0.05 \\
\hline Staple Length [4/5 mm (1/32 in.)] & 35.67 & 0.484 & 35.93 & 0.193 & 0.26 & 0.088 & 0.71 \\
\hline Upper Half Mean Length (mm) & 28.1 & 0.29 & 28.3 & 0.16 & 0.21 & 0.040 & 0.90 \\
\hline (in.) & 1.108 & 0.011 & 1.116 & 0.006 & 0.008 & & \\
\hline Micronaire & 4.531 & 0.424 & 4.527 & 0.300 & 0.004 & 0.948 & -0.01 \\
\hline Strength (g/tex) & 30.31 & 0.87 & 30.56 & 0.94 & 0.25 & 0.023 & 0.28 \\
\hline Uniformity Index (\%) & 81.31 & 0.23 & 81.47 & 0.16 & 0.16 & 0.037 & 0.82 \\
\hline
\end{tabular}

[a] Color grade determined from mean $\mathrm{Rd}$ and $+\mathrm{b}$ values.

[b] Cohen's d standardized effect size. 
Table 3. Means and statistics for AFIS fiber properties from feeder hopper moisture addition - Off \& On.

\begin{tabular}{|c|c|c|c|c|c|c|c|}
\hline & \multicolumn{2}{|c|}{ Off } & \multicolumn{2}{|c|}{ On } & \multirow[b]{2}{*}{ Diff } & \multirow[b]{2}{*}{ p-value } & \multirow[b]{2}{*}{$\mathrm{d}^{[\mathrm{a}]}$} \\
\hline & Mean & SD & Mean & SD & & & \\
\hline Length by wt. (mm) & 24.96 & 0.32 & 25.36 & 0.31 & 0.400 & 0.004 & 1.26 \\
\hline (in.) & 0.983 & 0.013 & 0.999 & 0.012 & 0.016 & & \\
\hline Length by wt. CV (\%) & 34.42 & 0.79 & 33.84 & 0.56 & 0.579 & 0.022 & -0.84 \\
\hline Upper Quartile Length by wt. (mm) & 30.26 & 0.45 & 30.64 & 0.32 & 0.38 & 0.024 & 0.98 \\
\hline (in.) & 1.191 & 0.018 & 1.206 & 0.012 & 0.015 & & \\
\hline Short Fiber Content by wt. (\%) & 8.90 & 0.61 & 8.38 & 0.55 & 0.515 & 0.010 & -0.89 \\
\hline Nep Count (per g) & 251 & 43.9 & 236 & 25.3 & 15.3 & 0.184 & -0.43 \\
\hline Seed Coat Nep Count (per g) & 12.6 & 1.87 & 12.4 & 3.17 & 0.16 & 0.857 & -0.06 \\
\hline Trash Count (per g) & 70.9 & 22.5 & 81.8 & 28.4 & 10.9 & 0.211 & 0.43 \\
\hline Dust Count (per g) & 434 & 155 & 478 & 194 & 44.5 & 0.464 & 0.25 \\
\hline Visible Foreign Matter (\%) & 1.36 & 0.32 & 1.56 & 0.52 & 0.20 & 0.169 & 0.47 \\
\hline
\end{tabular}

[a] Cohen's d standardized effect size

seed coat nep count were lower (better) and trash measurements higher (worse) for fiber ginned with feeder hopper moisture On than for fiber ginned with feeder hopper moisture Off, the differences were not significant and effect sizes were small. This was surprising since fiber moisture content at the gin stand and lint cleaner would be expected to affect nep production and fiber cleaning. This could be explained by the cotton having good maturity ( 4.5 micronaire), mature cottons are relatively less susceptible to forming neps, and being relatively clean ( 2 and 3 leaf grades), lint cleaning is less effective on cottons with less foreign matter.

Unlike the feeder hopper moisture addition, lint slide moisture addition did not significantly affect HVI or AFIS fiber properties and effect sizes were small (tables 4 and 5). For the HVI properties, no p-value was less than 0.08 and no standardized effect size (d) was higher than about \pm 0.6 . For AFIS properties, the p-values were larger $(>0.25)$ and effect sizes smaller $(<0.4)$. This would make sense for length measurements, as lint slide moisture addition occurs after processes that affect fiber length. It is interesting that moisture addition at the feeder hopper impacted fiber color (yellowness $[+b])$, but moisture addition at the lint slide appeared to have little effect. This result is an enigma, as it would be expected that if moisture had a direct effect on yellowness, then lint slide moisture addition with the greater influence on bale moisture would have had the more significant effect.

During textile processing, card waste from lint with added moisture at the feeder hopper was about $8 \%$ less than without added moisture (table 6). Card waste was about $6 \%$ higher for lint with moisture added at the lint slide, than without added moisture. These differences were small and statistically not different, and corresponding effect sizes were small.

With respect to yarn properties across all treatments, yarn count ranged from 21.0 to 19.4 tex $(28.1$ to $30.5 \mathrm{Ne})$, strength from 10.7 to $13.3 \mathrm{cN} /$ tex, elongation from $5.7 \%$ to $6.8 \%$, mass variation $\mathrm{CV}$ from $25.6 \%$ to $30.3 \%$, thin $(-50 \%)$ places per $1000 \mathrm{~m}$ from 1568 to 3536 , thick ( $+50 \%)$ places per $1000 \mathrm{~m}$ from 2247 to 3655 , neps $(+200 \%)$ per $1000 \mathrm{~m}$ from 487 to 1400 , and hairiness from 5.7 to 6.3 . While these

Table 4. Means and statistics for HVI fiber properties from lint slide moisture addition - Off \& On.

\begin{tabular}{|c|c|c|c|c|c|c|c|}
\hline & \multicolumn{2}{|c|}{ Off } & \multicolumn{2}{|c|}{ On } & \multirow[b]{2}{*}{ Difference } & \multirow[b]{2}{*}{$\mathrm{p}$-value } & \multirow[b]{2}{*}{$\mathrm{d}^{[\mathrm{b}]}$} \\
\hline & Mean & SD & Mean & SD & & & \\
\hline Reflectance (Rd) & 79.92 & 0.65 & 79.81 & 0.63 & 0.11 & 0.675 & -0.17 \\
\hline Yellowness $(+b)$ & 9.98 & 0.21 & 9.91 & 0.26 & 0.07 & 0.136 & -0.30 \\
\hline Color Grade ${ }^{[\mathrm{a}]}$ & 11 & & 11 & & & & \\
\hline Leaf Grade & 2.26 & 0.30 & 2.51 & 0.50 & 0.26 & 0.082 & 0.62 \\
\hline Staple Length (1/32 in.) & 35.92 & 0.29 & 35.69 & 0.44 & 0.23 & 0.132 & -0.61 \\
\hline Upper Half Mean Length (mm) & 28.25 & 0.22 & 28.22 & 0.28 & 0.03 & 0.721 & -0.13 \\
\hline (in.) & 1.112 & 0.009 & 1.111 & 0.011 & 0.001 & & \\
\hline Micronaire & 4.514 & 0.382 & 4.543 & 0.352 & 0.029 & 0.624 & 0.08 \\
\hline Strength (g/tex) & 30.45 & 0.82 & 30.42 & 1.00 & 0.02 & 0.838 & -0.02 \\
\hline Uniformity Index (\%) & 81.39 & 0.25 & 81.39 & 0.17 & 0.001 & 0.988 & 0.01 \\
\hline
\end{tabular}

[a] Color grade determined from mean $\mathrm{Rd}$ and $+\mathrm{b}$ values.

[b] Cohen's d standardized effect size.

Table 5. Means and statistics for AFIS fiber properties from lint slide moisture addition - Off \& On.

\begin{tabular}{|c|c|c|c|c|c|c|c|}
\hline & \multicolumn{2}{|c|}{ Off } & \multicolumn{2}{|c|}{ On } & \multirow[b]{2}{*}{ Diff } & \multirow[b]{2}{*}{ p-value } & \multirow[b]{2}{*}{$\mathrm{d}^{[\mathrm{a}]}$} \\
\hline & Mean & SD & Mean & SD & & & \\
\hline Length by wt. (mm) & 25.19 & 0.43 & 25.14 & 0.33 & 0.047 & 0.697 & -0.12 \\
\hline (in.) & 0.992 & 0.017 & 0.990 & 0.013 & 0.002 & & \\
\hline Length by wt. CV (\%) & 34.15 & 0.86 & 34.11 & 0.62 & 0.05 & 0.845 & -0.06 \\
\hline Upper Quartile Length by wt. (mm) & 30.48 & 0.47 & 30.43 & 0.40 & 0.04 & 0.771 & -0.10 \\
\hline (in.) & 1.200 & 0.018 & 1.198 & 0.016 & 0.002 & & \\
\hline Short Fiber Content by wt. (\%) & 8.66 & 0.73 & 8.63 & 0.53 & 0.03 & 0.851 & -0.05 \\
\hline Nep Count (per g) & 243 & 38 & 244 & 35 & 1.4 & 0.897 & 0.04 \\
\hline Seed Coat Nep Count (per g) & 12.3 & 2.3 & 12.7 & 2.9 & 0.4 & 0.665 & 0.15 \\
\hline Trash Count (per g) & 71.4 & 21.6 & 81.3 & 29.3 & 9.9 & 0.254 & 0.38 \\
\hline Dust Count (per g) & 439 & 147 & 472 & 201 & 33.1 & 0.584 & 0.19 \\
\hline Visible Foreign Matter (\%) & 1.38 & 0.34 & 1.54 & 0.51 & 0.16 & 0.281 & 0.36 \\
\hline
\end{tabular}

[a] Cohen's d standardized effect size. 
Table 6. Card waste (\%) for feeder conditioning hopper and lint slide moisture addition - Off \& On.

\begin{tabular}{lcclcccccc}
\hline & \multicolumn{2}{c}{ Off } & & \multicolumn{2}{c}{ On } & & & \\
\cline { 2 - 3 } Moisture Addition & Mean & SD & & Mean & SD & Diff & p-value & $\mathrm{d}^{[\mathrm{a}]}$ \\
\hline Feeder Hopper & 7.17 & 1.169 & & 6.62 & 0.789 & 0.55 & 0.087 & -0.55 \\
Lint Slide & 6.696 & 1.080 & & 7.101 & 0.947 & 0.406 & 0.196 & 0.40 \\
\hline
\end{tabular}

[a] Cohen's d standardized effect size.

average yarn quality measures were generally better for fiber without feeder hopper moisture addition (table 7) and with lint slide moisture addition (table 8), the differences were not significant and effect sizes were medium $(<0.8)$ to mostly small $(<0.5)$. This was not surprising, as the differences in fiber length and strength between moisture addition On and Off were either small, though significant, for the feeder hopper or insignificant for the lint slide.

Based on these statistics, fiber quality was generally better when moisture was added at the feeder hopper and generally worse when moisture was added at the lint slide. However, the differences in fiber properties between moisture addition and no moisture addition were small and mostly not significantly different. Also, the effect of adding moisture at either the feeder hopper or the lint slide had an opposite effect on yarn quality, yarn quality was generally better for fiber without moisture added at the feeder hopper and with moisture added at the lint slide. Again, these differences in yarn properties were small and not statistically significant.

\section{DESCRIPTIVE STATISTICS}

The data were further analyzed using descriptive statistics based on the four moisture treatment combinations to understand how the small differences in fiber properties and gin operation due to moisture addition might affect the value to the producer and gin facility. Bale classing data for the four moisture addition treatment combinations are shown in table 9. Color grade, based on average $\mathrm{Rd}$ and $+\mathrm{b}$ values, was 11 for all treatments. Leaf grade ranged from 2.28 to 2.56 and was slightly higher with lint slide moisture addition (Slide Only and Hopper+Slide). Staple length was either 35 or 36 (1 staple $=4 / 5 \mathrm{~mm}$ or $1 / 32 \mathrm{in}$.) and was highest with Hopper Only moisture addition. Micronaire, strength, and uniformity averaged $4.5,30.4 \mathrm{~g} / \mathrm{tex}$, and $81.4 \%$, respectively. The classing data yielded an overall average lint value based on the 2015 cotton loan (USDA Farm Service Agency, $2015)$ of about $\$ 1.24 / \mathrm{kg}(56.20 \notin / \mathrm{lb})$. Lint value was highest for the Hopper Only moisture addition $[\$ 1.254 / \mathrm{kg}$ $(56.88 \phi / 1 b)]$ and lowest with Slide Only moisture addition $[\$ 1.229 / \mathrm{kg}(55.74 \phi / \mathrm{lb})]$. For perspective, the difference equals $\$ 5.47$ per $218 \mathrm{~kg}(480 \mathrm{lb})$ bale. That would result in about $\$ 10 \mathrm{k}$ more for a farmer averaging 5 bales/ha ( 2 bales per acre) yield on 400 ha (1000 acres).

The differences in bale classing data among moisture addition treatment combinations do not readily explain the differences in lint value. For example, using the grades in table 9, the lint values calculated with the 2015 cotton loan price schedule (USDA Farm Service Agency, 2015) would be $\$ 1.263 / \mathrm{kg}(57.30 \notin / \mathrm{lb})$ for No Addition, Slide Only, and

Table 7. Means and statistics for yarn properties from feeder hopper moisture addition - Off \& On.

\begin{tabular}{|c|c|c|c|c|c|c|c|}
\hline & \multicolumn{2}{|c|}{ Off } & \multicolumn{2}{|c|}{ On } & \multirow[b]{2}{*}{ Diff } & \multirow[b]{2}{*}{ p-value } & \multirow[b]{2}{*}{$\mathrm{d}^{[\mathrm{a}]}$} \\
\hline & Mean & SD & Mean & $\mathrm{SD}$ & & & \\
\hline Count (tex) & 20.272 & 0.455 & 20.156 & 0.376 & 0.117 & 0.477 & -0.28 \\
\hline$(\mathrm{Ne})$ & 29.142 & 0.662 & 29.307 & 0.549 & 0.165 & 0.492 & -0.27 \\
\hline Tenacity (cN/tex) & 12.245 & 0.855 & 12.104 & 0.467 & 0.141 & 0.566 & -0.21 \\
\hline Elongation (\%) & 6.300 & 0.330 & 6.197 & 0.254 & 0.103 & 0.328 & -0.35 \\
\hline Mass Variation CV (\%) & 27.49 & 1.41 & 28.27 & 0.78 & 0.78 & 0.058 & 0.68 \\
\hline Thin Places $(-50 \% / \mathrm{km})$ & 2268 & 589 & 2504 & 314 & 236 & 0.140 & 0.50 \\
\hline Neps $(200 \% / \mathrm{km})$ & 785 & 266 & 979 & 253 & 194 & 0.086 & 0.75 \\
\hline Hairiness Index & 5.94 & 0.17 & 5.96 & 0.09 & 0.026 & 0.634 & 0.19 \\
\hline
\end{tabular}

[a] Cohen's d standardized effect size

Table 8. Means and statistics for yarn properties from lint slide moisture addition - Off \& On.

\begin{tabular}{|c|c|c|c|c|c|c|c|}
\hline & \multicolumn{2}{|c|}{ Off } & \multicolumn{2}{|c|}{ On } & \multirow[b]{2}{*}{ Diff } & \multirow[b]{2}{*}{$\mathrm{p}$-value } & \multirow[b]{2}{*}{$\mathrm{d}^{[\mathrm{a}]}$} \\
\hline & Mean & SD & Mean & SD & & & \\
\hline$\overline{\text { Count (tex) }}$ & 20.211 & 0.392 & 20.217 & 0.449 & 0.006 & 0.969 & 0.01 \\
\hline$(\mathrm{Ne})$ & 29.227 & 0.575 & 29.217 & 0.651 & 0.006 & 0.980 & -0.01 \\
\hline Tenacity $(\mathrm{cN} /$ tex $)$ & 12.157 & 0.736 & 12.192 & 0.646 & 0.036 & 0.885 & 0.05 \\
\hline Elongation (\%) & 6.260 & 0.284 & 6.238 & 0.314 & 0.022 & 0.835 & -0.07 \\
\hline Mass Variation CV (\%) & 27.965 & 1.189 & 27.80 & 1.231 & 0.165 & 0.669 & -0.14 \\
\hline Thin $(-50 \% / \mathrm{km})$ & 2448 & 514.29 & 2324 & 450 & 124.25 & 0.426 & -0.26 \\
\hline Thick $(50 \% / \mathrm{km})$ & 2877 & 372.74 & 2841 & 363 & 35.39 & 0.766 & -0.10 \\
\hline Neps $(200 \% / \mathrm{km})$ & 851 & 293.02 & 914 & 260 & 63.03 & 0.559 & 0.23 \\
\hline Hairiness Index & 5.96 & 0.17 & 5.94 & 0.10 & 0.02 & 0.689 & -0.16 \\
\hline
\end{tabular}

a] Cohen's d standardized effect size.

Table 9. Average bale classing data for the four moisture addition treatment combinations.

\begin{tabular}{|c|c|c|c|c|c|c|c|c|c|c|}
\hline \multirow{2}{*}{$\begin{array}{l}\text { Moisture } \\
\text { Addition } \\
\end{array}$} & \multirow{2}{*}{$\begin{array}{c}\text { Reflectance } \\
(\mathrm{Rd})\end{array}$} & \multirow{2}{*}{$\begin{array}{c}\text { Yellowness } \\
(+\mathrm{b})\end{array}$} & \multirow{2}{*}{$\begin{array}{l}\text { Color } \\
\text { Grade }\end{array}$} & \multirow{2}{*}{$\begin{array}{l}\text { Leaf } \\
\text { Grade }\end{array}$} & \multirow{2}{*}{$\begin{array}{c}\text { Staple } \\
{[4 / 5 \mathrm{~mm}(1 / 32 \mathrm{in} .)]}\end{array}$} & \multirow[b]{2}{*}{ Micronaire } & \multirow{2}{*}{$\begin{array}{l}\text { Strength } \\
(\mathrm{g} / \text { tex })\end{array}$} & \multirow{2}{*}{$\begin{array}{l}\text { Uniformity } \\
\text { Index } \\
(\%)\end{array}$} & \multicolumn{2}{|c|}{ Lint Value } \\
\hline & & & & & & & & & $(\$ / \mathrm{kg})$ & $(ф / 1 b)$ \\
\hline No Addition & 80.02 & 9.96 & 11 & 2.28 & 35.83 & 4.49 & 30.39 & 81.33 & 1.239 & 56.18 \\
\hline Slide Only & 79.94 & 9.81 & 11 & 2.47 & 35.51 & 4.57 & 30.23 & 81.30 & 1.229 & 55.74 \\
\hline Hopper Only & 79.82 & 10.01 & 11 & 2.23 & 36.00 & 4.53 & 30.50 & 81.46 & 1.254 & 56.88 \\
\hline Hopper+Slide & 79.67 & 10.01 & 11 & 2.56 & 35.87 & 4.52 & 30.62 & 81.49 & 1.234 & 55.98 \\
\hline
\end{tabular}


Hopper Only moisture addition and $\$ 1.249 / \mathrm{kg}(56.65 \varnothing / \mathrm{lb})$ for Hopper+Slide, all nearly the same. Exploring the distributions of classing variables for all the bales in each moisture addition treatment reveals how subtle differences in individual bale grade affected the average lint value for the moisture treatment combinations. Color grade distributions in figure 2 show that the majority $(>78 \%)$ of bales for all moisture addition treatments had white color grades 11 or 21, which have equivalent loan premiums. The Slide Only treatment had the fewest bales (8\%) with light spotted grades (12 or 22), which agrees with the lowest average yellowness of $9.81+b$ for Slide Only. Twenty-two percent of the bales with Hopper+Slide moisture addition had light spotted grades. Considering leaf grade in figure 2, more than $70 \%$ of bales processed with Hopper Only moisture and No Addition had 1 and 2 leaf grade, which have equivalent loan premiums. Within the two treatment combinations that added lint slide moisture (Slide Only and Hopper+Slide), about half of the bales had a 1 or 2 leaf grade. The significant effect of feeder hopper moisture on fiber length was shown earlier. This is supported by the data in figure 2 where $100 \%$ of the bales with Hopper Only moisture addition had 36 staple length. These HVI properties are used together in the cotton loan schedule to determine premiums or discounts as part of the cotton lint valuation calculation. Figure 3 shows the distributions of cotton loan premiums based on the bale color, leaf, and staple length grades for the four moisture addition treatment combinations. The Hopper Only treatment had consistently more bales with color/leaf/staple grade combinations resulting in higher cotton loan premiums; $85 \%$ of these bales had a 445 point or higher color/leaf/staple premium. Bales with No Addition had the next highest percentage of bales $(72 \%)$ with a 445 point or higher color/leaf/staple premium.

Figure 4 shows the bale distributions across moisture addition treatment combinations for micronaire, strength, and uniformity. There were no bales with Hopper Only moisture addition that had micronaire readings above 4.9 with a -260 point discount, while the other treatments had nearly $20 \%$ or

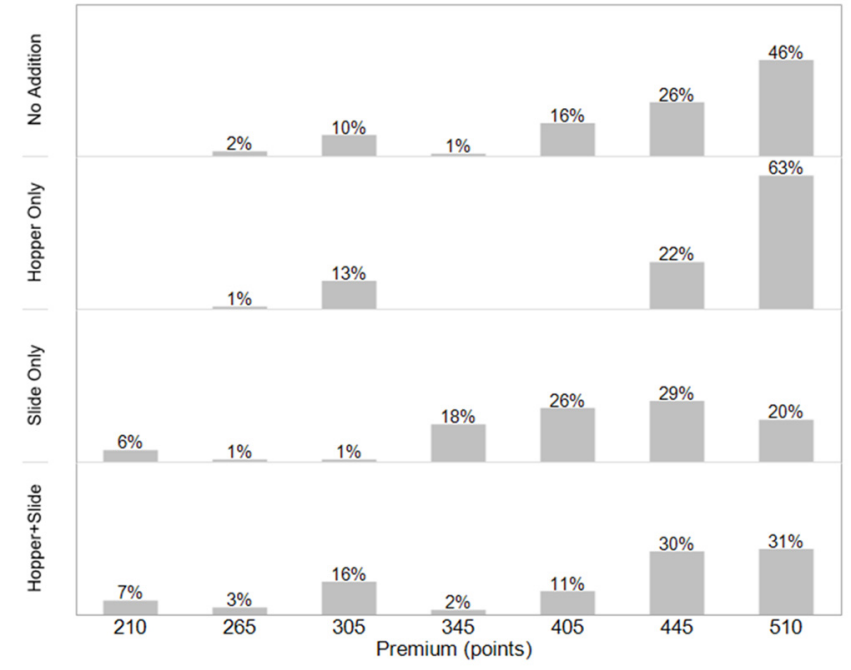

Figure 3. Percentage distribution of bale cotton loan premiums based on color, leaf, and staple length grades for the four moisture addition treatment combinations.

more bales in that discount range. Forty-eight percent of the bales from the Hopper+Slide moisture addition treatment had $31 \mathrm{~g} /$ tex and higher strength, which corresponds to a 40 point premium. Similar to the other HVI properties, the Hopper Only treatment had the most bales in the higher strength premium ranges ( $62 \%$ at 20 or more points). The length uniformity of all bales, regardless of moisture addition treatment, was in the zero premium/discount range, $80.0 \%$ to $81.9 \%$.

HVI property distributions in figures 2 and 4 show how subtle differences led to higher cotton loan premiums and thus, higher average lint value for bales with Hopper Only moisture addition. Table 10 shows the average cotton loan premiums/discounts by treatment combination. The Hopper Only moisture treatment had more bales with HVI properties in the higher premium ranges for color/leaf/staple, micronaire, strength, and uniformity that resulted in higher total premiums and lint value.

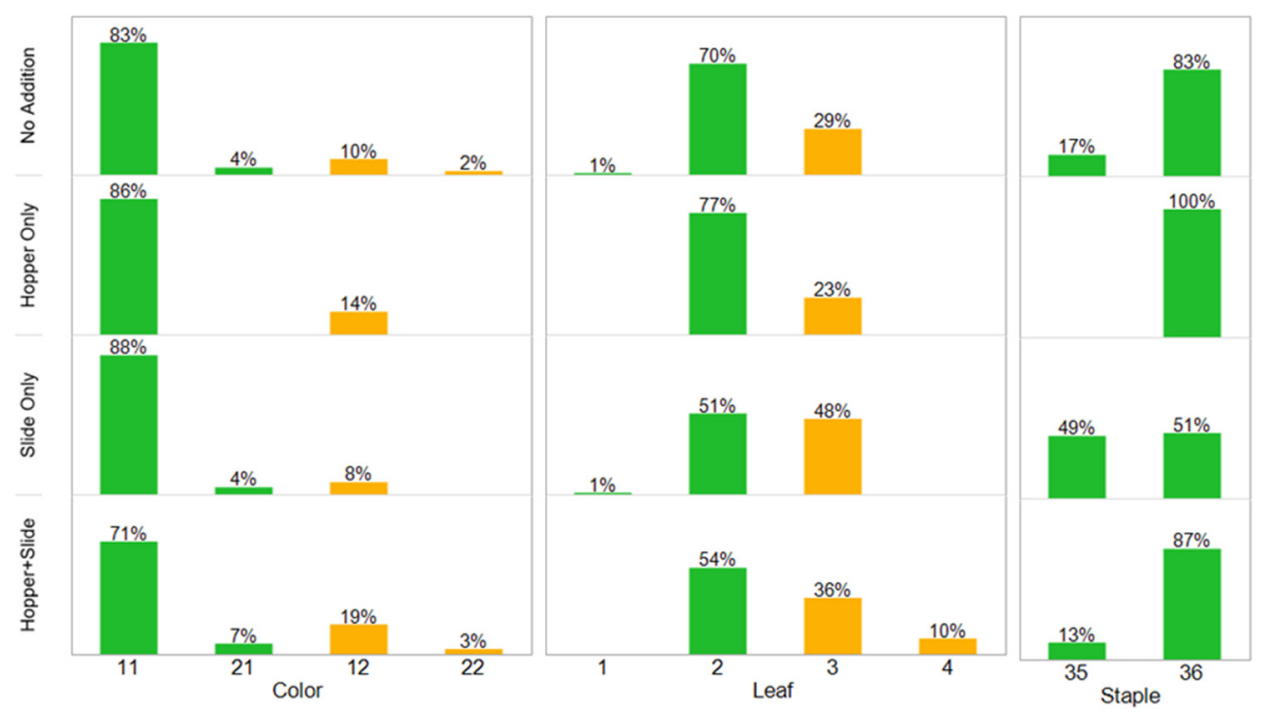

Figure 2. Percentage distribution of bale color, leaf, and staple length grades for the four moisture addition treatment combinations. Grades with the same colored bars have the same premium level. 


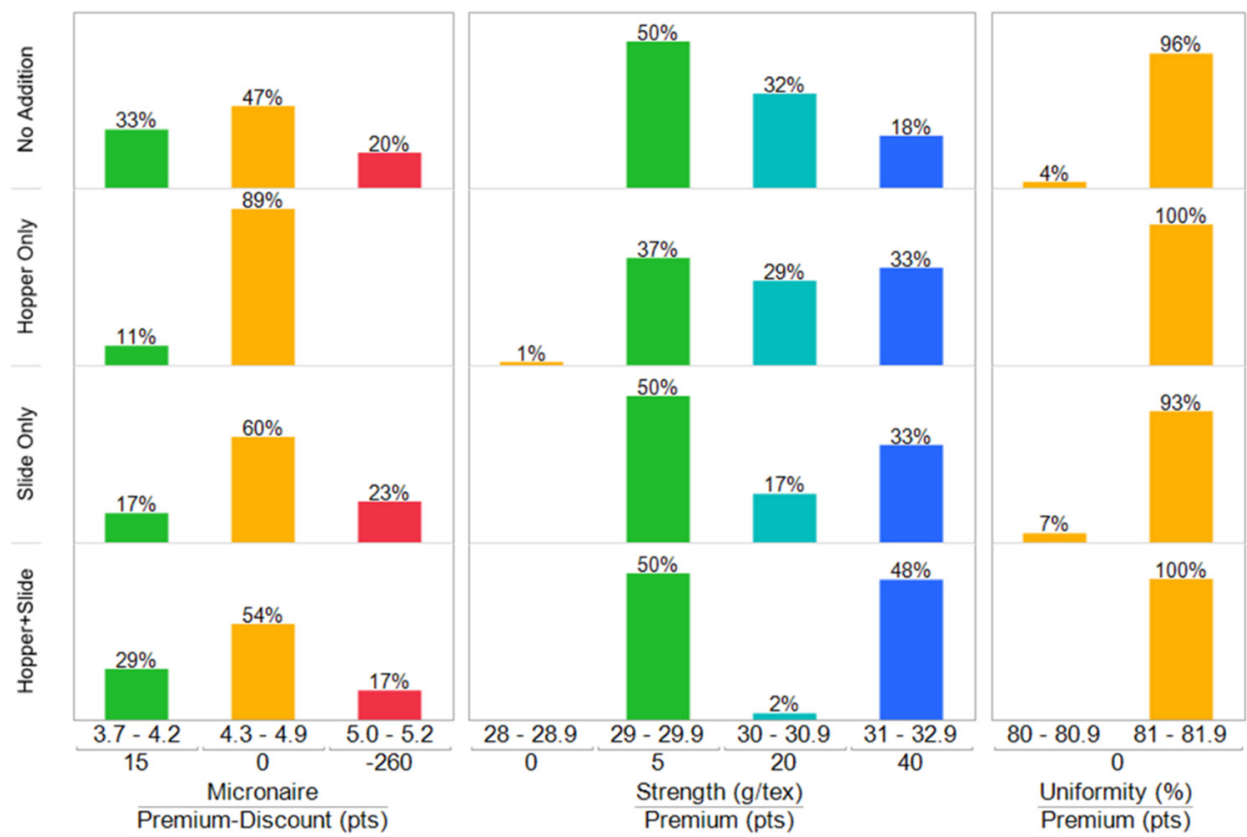

Figure 4. Percentage distribution of bale micronaire, strength, and uniformity grades for the four moisture addition treatment combinations. Grades with the same colored bars have the same premium level.

As seen in figure 5, bale weight increased from $215 \mathrm{~kg}$ (475 lb) for No Addition to $224 \mathrm{~kg}$ (495 lb) for Hopper+Slide moisture addition. This increase in bale weight offset lower lint value, resulting in bale values of $\$ 267, \$ 273, \$ 272$, and \$277 for No Addition, Hopper Only, Slide Only, and Hopper+Slide, respectively.

The increase in bale weight was not only due to increased bale moisture content. As seen in figure 6, average bale moisture content was similar between No Addition (4.25\%) and Hopper Only addition (4.21\%). This was expected since any moisture added would likely be lost during lint cleaning and conveying. Average moisture content with lint slide moisture addition was about $5.1 \%$. The $9 \mathrm{~kg}(20 \mathrm{lb})$ difference in bale weight between No Addition and Hopper+Slide addition can only be accounted for by about $2.4 \mathrm{~kg}(5.3 \mathrm{lb})$ of moisture; the remaining difference was about $7 \mathrm{~kg}(15 \mathrm{lb})$ more dry cotton lint per bale. More dry cotton per bale suggests that fewer bales would need to be pressed with moisture addition for the same amount of cotton with no moisture addition. Using the information in figure 6 for example, the amount dry cotton in 100 bales produced with No Addition $[20,600 \mathrm{~kg}(45,400 \mathrm{lb})]$ could be pressed into only about 97 bales produced with Hopper+Slide moisture addition.

Table 10. Average cotton loan color/leaf/staple, micronaire, strength, and uniformity premium/discount (points) for the four moisture addition treatment combinations.

\begin{tabular}{lccccc}
\hline \multicolumn{1}{c}{$\begin{array}{c}\text { Moisture } \\
\text { Addition } \\
\text { Treatment } \\
\text { Combination }\end{array}$} & $\begin{array}{c}\text { Color/Leaf/ } \\
\text { Staple }\end{array}$ & Micronaire & Strength & Uniformity & Total \\
\hline No Addition & 449 & -47 & 16 & 0 & 418 \\
Slide Only & 413 & -58 & 19 & 0 & 374 \\
Hopper Only & 466 & 2 & 21 & 0 & 488 \\
Hopper+Slide & 415 & -39 & 22 & 0 & 398 \\
\hline
\end{tabular}




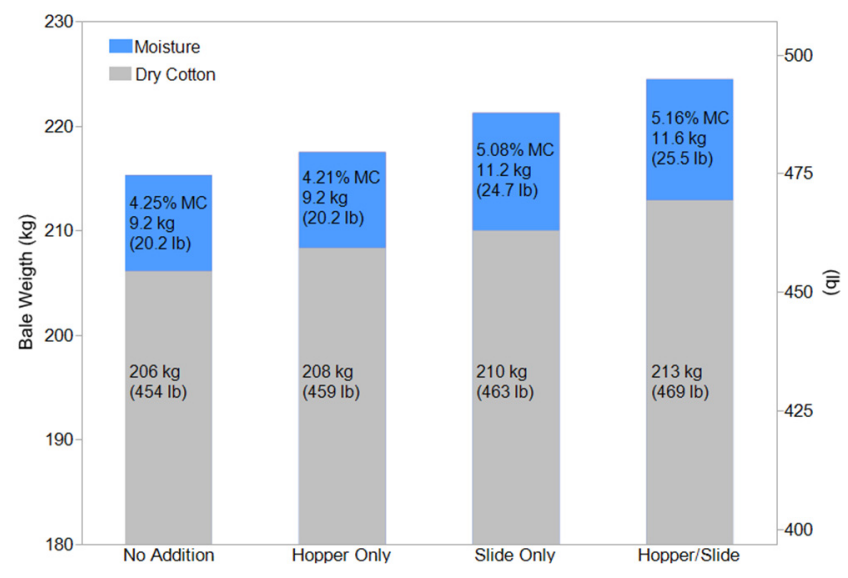

Figure 6. Average bale dry lint and moisture weight for the four moisture addition treatment combinations.

More lint per bale can likely be attributed to less press power needed for higher moisture bales up to the required maximum of $7.5 \%$ MC w.b. (Valco et al., 2004). Average power to press a bale was about $2 \mathrm{~kW}$ less when lint slide moisture (Slide Only and Hopper+Slide) was applied, and total energy used to press a bale averaged about $0.05 \mathrm{~kW}-\mathrm{h}$ less with lint slide moisture (fig. 7). Heavier bales with more dry matter and less press power required to press these bales could lead to less press wear, but this is difficult to quantify. Gas usage to operate the moisture systems was about 221, 668 , and $833 \mathrm{~L}\left(7.8,23.6\right.$, and $\left.29.4 \mathrm{ft}^{3}\right)$ per bale higher for the Hopper Only, Slide Only, and Hopper+Slide moisture addition treatments than for No Addition.

To understand the practical significance of adding moisture before ginning and/or before baling cotton, the average cotton variables and operating cost variables were included in an analysis that determined the added value and cost to produce 10,000 bales of cotton. Cotton variables included lint value, bale weight, and moisture content; and operating cost variables included electrical energy to operate the press and feeder hopper and lint slide moisture systems, natural gas usage, bale bagging and ties, and labor. As can be seen in table 11, the additional moisture and heavier average bale weight from moisture addition, especially with the lint slide moisture addition (Slide Only and Hopper+Slide), resulted in fewer bales for the equivalent amount of dry lint, 318 fewer bales with Hopper+Slide moisture addition than with No Addition. Also, added moisture and lint value combine to result in added value ranging from $\$ 1,512$ for 9,816 equivalent bales ( $\$ 0.15$ per bale) with Slide Only moisture to $\$ 32,749$ for 9,894 equivalent bales (\$3.31 per bale) with Hopper Only moisture addition.

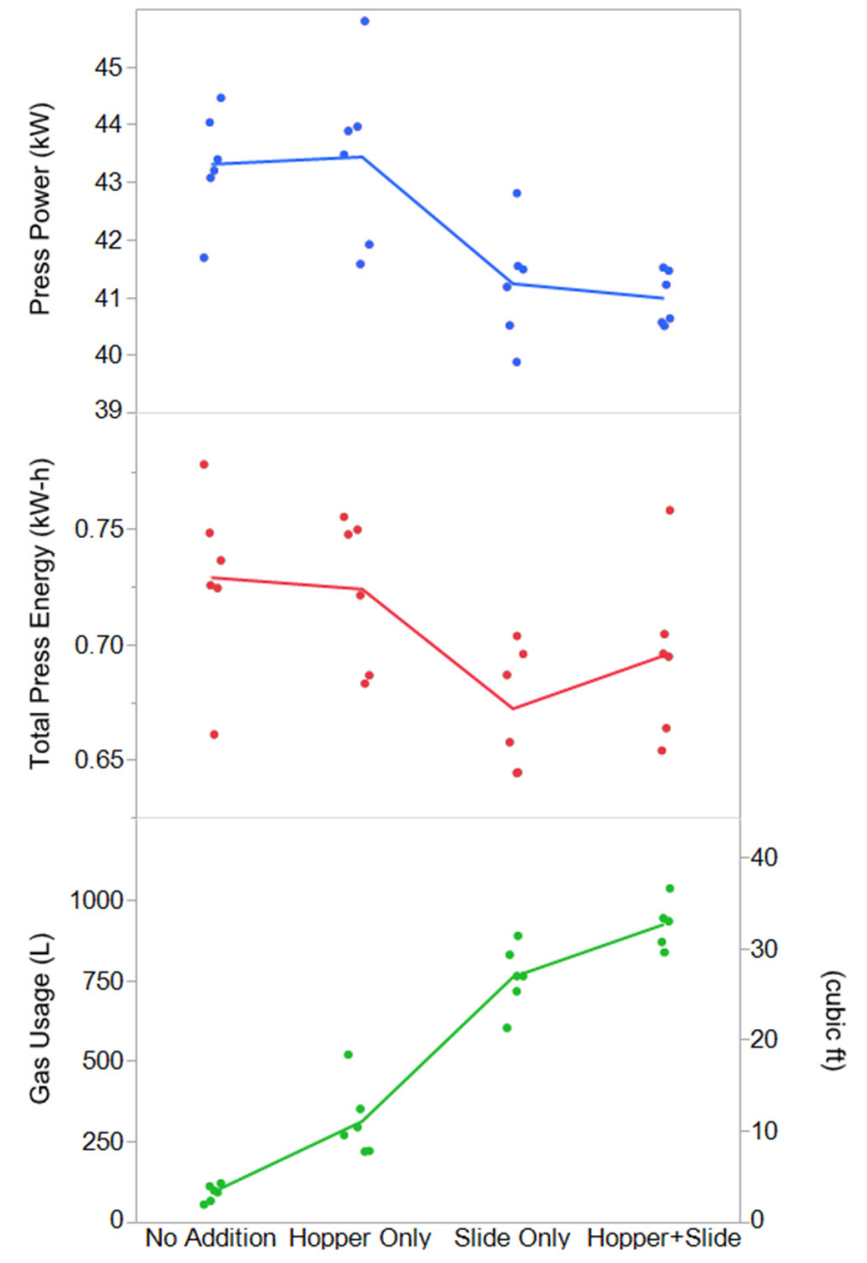

Figure 7. Average press power and energy consumed to press bales, and natural gas usage for the four moisture addition treatment combinations.

Estimates for the cost to operate the moisture systems based on the energy consumed by the bale press and feeder hopper and lint slide moisture systems energy, and the cost per bale for bagging and ties and labor are shown in table 12. The cost of electricity and natural gas, $\$ 0.064 / \mathrm{kWh}$ and $\$ 0.85 /$ Therm, respectively, were provided by the management of the gin where testing occurred. The cost of bale bagging and ties and labor were estimated at $\$ 4.78$ and $\$ 7.91$ per bale, respectively (Valco et al., 2015). The combined energy cost ranged from $7.7 \notin /$ bale for Hopper Only to $26.9 \notin /$ bale for Hopper+Slide moisture addition with natural gas making up the majority of the cost. The bale bagging/ties and labor savings due to ginning fewer bales completely offset the added energy cost resulting in a small savings to operate the moisture systems. These savings ranged from $\$ 298$ to $\$ 1,429$ for the equivalent of 10,000 bales ginned without moisture.

Table 11. Value of $\mathbf{1 0 , 0 0 0}$ equivalent bales for the four moisture addition treatment combinations.

\begin{tabular}{|c|c|c|c|c|c|c|c|c|c|c|}
\hline \multirow{2}{*}{$\begin{array}{l}\text { Moisture } \\
\text { Addition }\end{array}$} & \multicolumn{2}{|c|}{ Bale Wt. } & \multirow{2}{*}{$\begin{array}{c}\text { Bale MC } \\
(\%)\end{array}$} & \multicolumn{2}{|c|}{$\begin{array}{l}\text { Dry Lint } \\
\text { per Bale }\end{array}$} & \multirow{2}{*}{$\begin{array}{c}\text { Equivalent } \\
\text { Bales }\end{array}$} & \multicolumn{2}{|c|}{ Lint Value } & \multirow{2}{*}{$\begin{array}{c}\text { Total Value } \\
(\$)\end{array}$} & \multirow{2}{*}{$\begin{array}{c}\operatorname{Diff}^{[\mathrm{a}]} \\
(\$)\end{array}$} \\
\hline & $(\mathrm{kg})$ & (lb) & & $(\mathrm{kg})$ & (lb) & & $(\$ / \mathrm{kg})$ & $(\phi / l b)$ & & \\
\hline No Addition & 215 & 475 & 4.25 & 206 & 454 & 10000 & 1.239 & 56.18 & $2,668,550$ & -- \\
\hline Slide Only & 221 & 488 & 5.08 & 210 & 463 & 9816 & 1.229 & 55.74 & $2,670,062$ & 1512 \\
\hline Hopper Only & 217 & 480 & 4.21 & 208 & 459 & 9894 & 1.254 & 56.88 & $2,701,299$ & 32749 \\
\hline Hopper+Slide & 224 & 495 & 5.16 & 213 & 469 & 9682 & 1.234 & 55.98 & $2,682,892$ & 14342 \\
\hline
\end{tabular}

[a] Difference between total value for Moisture Addition treatments and No Addition. 
Table 12. Average added energy and operating cost to process 10,000 equivalent bales with moisture addition treatments compared to no moisture addition.

\begin{tabular}{|c|c|c|c|c|c|c|c|c|c|c|c|}
\hline \multirow{3}{*}{$\begin{array}{l}\text { Moisture } \\
\text { Addition }\end{array}$} & \multicolumn{3}{|c|}{ (kW-h/bale) } & & & \multirow{3}{*}{$\begin{array}{c}\text { Energy } \\
\text { Cost } \\
\text { (\$/bale) }\end{array}$} & \multirow{3}{*}{$\begin{array}{c}\text { Equivalent } \\
\text { Bales }\end{array}$} & \multirow{3}{*}{$\begin{array}{c}\text { Total } \\
\text { Cost } \\
(\$)\end{array}$} & \multirow{3}{*}{$\begin{array}{c}\text { Bale Bag/Tie } \\
\text { Savings } \\
(\$)\end{array}$} & \multirow{3}{*}{$\begin{array}{l}\text { Labor } \\
\text { Savings } \\
(\$)\end{array}$} & \multirow{3}{*}{$\begin{array}{l}\operatorname{Diff}^{[\mathrm{a}]} \\
(\$)\end{array}$} \\
\hline & Press & Hopper & Lint Slide & \multicolumn{2}{|c|}{ Gas Usage } & & & & & & \\
\hline & Energy & Energy & Energy & (L/bale) & $\left(\mathrm{ft}^{3} /\right.$ bale $)$ & & & & & & \\
\hline No addition & 0 & 0 & 0 & 0 & 0 & 0.000 & 10000 & 0 & 0 & 0 & 0 \\
\hline Slide only & -0.057 & 0 & 0.065 & 668 & 23.6 & 0.208 & 9816 & 2037 & -880 & -1455 & -298 \\
\hline Hopper only & -0.005 & 0.146 & 0 & 221 & 7.8 & 0.077 & 9894 & 766 & -507 & -838 & -579 \\
\hline Hopper+Slide & -0.034 & 0.146 & 0.065 & 833 & 29.4 & 0.269 & 9682 & 2607 & -1520 & -2515 & -1429 \\
\hline
\end{tabular}

[a] Total cost minus savings.

\section{CONCLusions}

Testing was conducted at a western commercial cotton gin to evaluate the effect of humid air moisture addition on fiber quality, bale value, and operating costs; when applied at the gin stand feeder conditioning hopper and battery condenser lint slide. Humid air moisture addition at the feeder hopper increased seed cotton moisture content by 0.10 percentage points and at the lint slide increased bale moisture content by about 0.9 percentage points. Feeder hopper moisture addition resulted in small, but significant, improvements in HVI length, uniformity, and strength and AFIS length and short fiber content. However, color yellowness increased due to feeder hopper moisture addition. Lint slide moisture addition had very little effect on fiber quality. Moisture addition at either location did not significantly affect spinning performance or yarn quality. Lint produced with moisture added only at the feeder hopper had the highest average value, and lint produced with moisture added only at the lint slide had the lowest value. Bales produced with added moisture were heavier, not only because of the increased moisture, but also because they contained more dry lint. This could be due to easier pressing of the higher moisture lint, which was supported by less press power consumed for bales with moisture added at the lint slide. When the bale data were extrapolated to 10,000 bales, results showed that fewer bales would be produced by adding moisture due to the increased dry lint per bale compared to no moisture addition. Also, adding moisture at the feeder hopper resulted in the greatest overall increase in cotton value over the value of cotton ginned with no moisture addition, more than $\$ 32,000$ when extrapolated over 10,000 bales. Adding moisture required more energy to produce a bale, mainly from the additional natural gas needed to humidify the air. However, since bales with added moisture contained more dry lint resulting in fewer bales pressed, savings in bale packaging materials and labor costs made operating the moisture systems slightly less expensive than not, up to about $\$ 1400$ less for 10,000 bales with the Hopper+Slide moisture addition. Although the results showed little impact on cotton quality by adding moisture, the subtle differences and heavier bales containing more lint could have a significant effect on the value to a producer over an entire cotton crop or to a gin over an entire season.

\section{ACKNOWLEDGEMENTS}

The authors would like to thank Samuel Jackson, Inc. for their help in ensuring that the moisture systems used in this research were set-up and running properly throughout testing. Also, thanks to the Yuco Gin for allowing testing at their facility and providing support during the testing.

\section{REFERENCES}

Anthony, W. S. (2002). Impact of moisture added at lint slide on cotton color. Cotton Gin and Oil Mill Press, 8-12.

Anthony, W. S. (2004). Survey of moisture restoration at midsouth gins in 2003. Cotton Gin and Oil Mill Press, 8-11.

ASTM. Int. (2016). Standard test method for breaking strength of yarn in skein form. West Conshohocken, PA: ASTM Int. Retrieved from www.astm.org

Baker, K. D., Hughs, E., \& Chun, D. T. (2008). Use of a rotor spray system for moisture addition to cotton lint. Appl. Eng. Agric., 24(4), 491-495. https://doi.org/10.13031/2013.25133

Boykin, J. C. (2005). The effects of dryer temperature and moisture addition on ginning energy and cotton properties. J. Cotton Sci., 9(2), 155-165.

Byler, R. K. (2005). The effect of modest moisture addition to seed cotton before the gin stand on fiber length. J. Cotton Sci., 9(2), $145-154$.

Byler, R. K. (2008). Seed cotton moisture restoration in a commercial gin. Appl. Eng. Agric., 24(5), 587-591. https://doi.org/10.13031/2013.25271

Byler, R. K., Gamble, G. R., \& Boykin, J. C. (2008). Quality effects from the addition of moisture to seed cotton with two surfactants. J. Cotton Sci., 12(4), 345-356.

Childers, R. E., \& Baker, R. V. (1978). Effect of moisture conditioning on ginning performance and fiber quality of High Plains cotton. Trans. ASAE, 21(2), 379-384. https://doi.org/10.13031/2013.35308

Chun, D. T., Hughs, S. E., Armijo, C., Baker, K. D., \& McAlister, D. D. (2007). A study of bale moisture addition. Trans. ASABE, 50(2), 325-330. https://doi.org/10.13031/2013.22622

Cohen, J. (1988). Statistical power analysis for the behavioral sciences (2nd ed.). Hillsdale, NJ: Lawrence Earlbaum Assoc.

Cotton. (2015). General eligibility requirements, 7CFR1427.5.

Funk, P. A., Hardin IV, R. G., Hughs, S. E., \& Boykin, J. C. (2013). Changes in cotton gin energy consumption apportioned by 10 functions. J. Cotton Sci., 17(2), 174-183.

Hughs, S. E., Mangialardi Jr., G. J., \& Jackson, S. G. (1994). Moisture control. In W. S. Anthony, \& W. D. Mayfield (Eds.), Cotton ginners handbook (pp. 58-68). Washington, DC: USDA.

Shepherd, J. V. (1972). Standard procedures for foreign matter and moisture analytical tests used in cotton ginning research. Washington, DC: USDA.

USDA Farm Service Agency. (2015). 2015-crop upland cotton schedule of premiums and discounts. Washington, DC: USDA. Retrieved from https://www.fsa.usda.gov/Assets/USDA-FSAPublic/usdafiles/PriceSupport/pdf/2016/2015.cotton.premiums.discounts.pdf

Valco, T. D., Ashley, H., Findley, D. F., Green, J. K., Isom, R. A., Price, T. L., \& Fannin, J. M. (2015). The cost of ginning cotton 2013 survey results. Proc. Beltwide Cotton Conf. (pp. 523-526). Cordova, TN: National Cotton Council.

Valco, T. D., Byler, R. K., Pelletier, M. G., Hughs, S. E., \& Norman, W. M. (2004). Moisture restoration of cotton. Cotton Gin and Oil Mill Press, 5-8. 